\title{
Free Time versus Occupied and Unoccupied Time in a Philosophical Context
}

Authors' contribution:

A) conception and design of the study

B) acquisition of data

C) analysis and interpretation of data

D) manuscript preparation

E) obtaining funding

\author{
Jerzy Kosiewicz
}

Josef Pilsudski University of Physical Education in Warsaw, Poland

ABSTRACT

In the paper, previous conceptions of free time and the various definitions that are connected with it are challenged. The author assumed that the subject might not have free time at his/her disposal, because that time does not concern the subject at all. The subject did not have free time in the past; the subject can neither shape it in the present nor in the future. Free time does not concern him/her at all, because free time as such does not exist at all. We have only to do with occupied and unoccupied time. The first form of time concerns the past and the present. Future time is not occupied both in that sense that it does not exist yet and that it never exists.

Moreover, the author considers the existence, understanding, and possibility of the cognition of time as such. Thus, he rejects various common theories of time. He refers to the Kantian, subjective, "self-related" conception of time and he attempts to strengthen it with the Heideggerian transcendental theory of time. According to the author, it is derived from, among other things, the considerations on being done by some of the ancient philosophers: Anaximander, Pythagoras and his followers, Parmenides, Plato, and Aristotle.

KEYWORDS leisure, history, occupied time, unoccupied time, being, Kantian theory of time, Heideggerian theory of time

Following an interesting discussion that took place after the presentation of the paper A Dispute on the Existence of Free Time during a conference organized by the British Philosophy of Sport Association in Cardiff in May 2006, I decided to supplement the paper with new reflections which are important from my viewpoint. The ones that concern mysticism, prayer, and the situation of the prisoner and the slave have been incorporated into Part I of the text; the rest are placed in Part II. Because the present paper is much larger that the initial version, I have decided to change the earlier title to a new one that better expresses its contents.

\section{A Dispute about the Existence of Free Time}

\section{Free time, occupied time and unoccupied time}

The aim of this disquisition is not in the least to give an account of the dispute about the existence of free time. Generally, I have no information about such a dispute. It concerns rather my questioning the existence of free time as such and the contexts of my justifying a thesis on the existence of that time. As a consequence, it leads to an argument with those kinds of views. 
Namely, I am of the opinion - perhaps a perverse one - that if it is assumed, according to the most often applied distinctions, that free time is free since it is free of work, it may, paradoxically, turn out that all we do, all we perform, all our conduct, all activities connected with work, with duties, as well as the other various activities of a physical, mental or relational character (the last of them are activities related to other persons or sacral beings in the religious and non-religious sense) take place in time free of other forms of activity, that is, of actions concerning work or unconnected with it, which may have pleasant or not very pleasant qualities. I emphasize once again that all we do is always done in time free of other occupations connected or unconnected with other duties. Simply put, we can do nothing more in the time that is already occupied by us (Kosiewicz 2006).

Even if we spend time in a pleasant way, it is filled up time, time occupied by pleasures. It's not time free of pleasures, but filled up with them - that is, it's busy, not free, time. Thus, the next pleasures may take place (other forms of activities may occur) only after the completion of the previous activities, which means: in time free of the previous activities.

According to this understanding, free time means time unoccupied by anything else, and using the existing/common/accepted interpretation of free time, which (if understood in the broadest possible sense) meant time free of work, loses its significance and even becomes senseless.

This viewpoint is confirmed in a sense by Aristotle, who proclaims in Nicomachean Ethics that "Free time is not the end of work, but work is the end of free time, which should be devoted to art, studies and, first of all, to philosophy". It follows from this definition - regardless of what is the end of what and how much free time is appreciated - that that time, similar to working time, is not free of activities. Quite the opposite: it should be filled up either with art, or with studies, or with philosophy. And if it is filled, it is not free. Moreover, I call your attention to the fact that although occupying oneself with art, studies or philosophy may bring pleasure, it is usually connected with time-consuming and exhausting work. I experience it myself when dealing with theatre, teaching, and philosophy (Kosiewicz 2006).

Regarding further issues of free time, not so much from the viewpoint of Nicomachean Ethics, but from the social perspective characteristic for the age of slavery, it is possible to proclaim that this type of time is the time of free people, who, unlike slaves, have freedom, have time which is free - independent from serfdom - at their disposal. We may imagine that if they are free, their time is also free. Its value, therefore, is enhanced in two ways: with freedom from and freedom for. That free people are free, for example, from the obligation to work, from the will and decisions of slave owners. That free people have also freedom to undertake any activity connected with the status of the free man. However, regardless of the situation of free people or their place in the hierarchy of the ancient society (and not only of it), time they could or can have at their disposal - regardless of what it is called - is always occupied time.

\section{Free Time and Consciousness}

According to the interpretation I propose, we are dealing with occupied time and unoccupied time that is, with free time (free, since it is not occupied). However, free time - that is, time that is not occupied at all - does not exist. Regarding man as a being conscious of his existence, it may be assumed that free time never currently - that is, in the time being, at present - exists. Free time is time of abstract, conceptual qualities. It may only be envisaged by the subject and may regard the future (although not exclusively).

In connection with the above statements, man beyond consciousness is the only form of the human being who possesses free time, although there is no way he could realize what he possesses. The fact that he has free time is known by other people, but not by the discussed person. The discussed person cannot determine how he uses that time, in contrast to other individuals keeping the unconscious being alive.

It may be also said - referring to the views of the Protestant thinker J. Moltmann - that man has free time (in a similar sense of the word) after the death of the soul and the body - while he waits first for resurrection, and then for salvation. M. Luther - Moltmann's precursor - proclaimed the theory of the "sleep 
of the soul", the view called hypnopsychism. He maintained that when man departs, his body dies and waits together with the soul, utterly passive at that time - which, by the way, is not occupied by anything, since the soul has sunk into something like a lethargic sleep - for the Last Judgment (Moltmann 1995).

Of course, man - a being who in a biological sense does not exist anymore - is given, from the viewpoint of Moltmann's views, free time which belongs to him, time free of everything. However, there is no way he could make use of it, since he is conscious neither of his gifts nor of the possibilities connected with them, since he does not know - and cannot know - that the break between the earthly life and the resurrection for the eternal life in an eschatological perspective is spare time for him, which is utterly free of any form of human activity (Kosiewicz 2003).

On the other hand, for the man conscious of his existence, the past has been always a busy time - time occupied by something that was of greater or lesser importance for him. Thus, there was never any free time in the past. Moreover, the past is time that does not belong to us and does not depend on us anymore, since it has irretrievably passed. And the real state of this time - that is, its real contents, which no longer exist anywhere except in memories - will never undergo any change. It can be treated as free time in another sense: free of our influence, of any interference in its real contents and structure.

Exceptions in this respect may only be recollective modifications or confabulations; fabrications of something that, in fact, neither exists nor has never existed.

\section{Mythology, mystical experiences, and prayer according to temporal interpretation}

The aforementioned confabulations pointing out the existence of free time appear in holy books, such as in biblical records taking into account the existence of paradise or heaven. Thus, they exist in the realm of considerations connected with the religiously determined supra-natural world.

Its existence is recognized and confirmed by believers of a given faith. Scholars and philosophers coming from beyond their circle do not share in that opinion. They have not found sufficient argumentation of a logical character concerning this issue. Also, there are no reasons to presume on those grounds that free time being present in scriptural records exists, since there are doubts about the existence of the supernatural world where that time is supposed to be.

The so-called suspension of time - that is, the suspension of its passing, of its influence - may be regarded in a similar way. It reportedly takes place during vertical communication - for example, between a clergyman and the religious Absolute. During that contact (according to theologians and philosophers of religious provenance), even direct contact with God may take place. It means a phenomenon of a mystical character - that is, mystical ecstasy when man, and especially his soul, undergoes a longer or a shorter (depending on a given thinker's opinions) annihilation or dissolution in a supernatural being. Due to that, and because of God's absolute causative power, the existence of man as an autonomous corporeal/spiritual being becomes suspended in the limited time. The soul dissolved in God loses human properties, since - in an act of absolute bliss - it permeates into and dissolves in something that is fully ideal. Hence, bodily functions of the human body temporarily deprived of the soul (which, as a matter of fact, animates the body) stop. It remains from that viewpoint in something like lethargy - it exists as if beyond time - until the revitalization of the human being, the reunification of the soul with the body, takes place.

Aurelius Augustine proclaims, for example, that during mystical unification the human soul does not dissolve into God; instead, the subject exists separately as a fully autonomous being, that it cognizes the truth in an act of divine illumination delighting in that form of mystical elation from a distance (which is simultaneously a specific ecstasy of an epistemic character - direct and non-cognitive - as epistemological reflection comes later). In contrast with the earlier form of experience, in which case we are dealing with external (extrospective, but non-sensual) perception, with partner-like unification of two subjects that are autonomous (in the ontological sense): the divine and the human. In the case of Aurelius Augustine's views, 
this does not mean, however, that there is no suspension of time when a given subject communes with the Absolute (Kosiewicz 2004b).

According to that philosopher, the discussed union, called also direct grace, may concern any person chosen by God. He may grant it even to some bloody villain or foul, lecherous woman. Divine vertical communication occurs, as in the case of the prayer of a strong believer who loses their sense of time, and it seems to him that it alienates him from the whole social and natural context and that he enters a new metaphysical sacral dimension, that he exists out of time (Kosiewicz 2004b).

However, that illusion - both in the case of mystical elation and during the prayer mentioned above does not mean that real suspension of time takes place. That time still passes, in spite of the fact that the ecstatic or praying subject does not perceive it, that it seems to him that - because of that extremely exceptional situation - it has been stopped or annihilated especially for him, while the psyche, dedicated to higher emotional experiences, and the organic body, which is connected with it, still function during that elation. Thus, that suspension concerns neither the individual, nor the social and natural environment that is connected with him.

Even if it is assumed that that suspension is a form of free time or liberation from worldly time, in the first case that time is occupied by ecstasy and in the second, the subject is entangled in that experience too, because it experiences mysticism. A given experience is not only an epistemological category, but also a temporal category, since the experience exists in time: it lasts shorter or longer. Anyone who experiences is not free of experience - he is a subject who is made busy by that experience. Both during the first and the second form of mystical unification, as well as during prayer, the subject - from the viewpoint of autonomous philosophy - is busy; the notion of free time does not concern him.

\section{On the prisoner and the slave}

There may arise a doubt concerning the situation of the prisoner who is deprived of any possibility of creative or non-creative activity during the time of serving a sentence and who - colloquially speaking - has too much free time.

Regarding that issue: from the viewpoint of research (theoretical convention) adopted in this text, it may be stated that the time the prisoner has at his disposal is only seemingly free time, since, as a matter of fact, it is fully-occupied time. The prisoner has lost his freedom, thus his time is fully occupied - seized by the punishment resulting from regulations of the penal code, which have been ruthlessly imposed on him. The prisoner's time is fully occupied, even if he is absolutely passive and is not busy with anything, he does nothing; that is, he is not active in any way. His seemingly absolutely free time is fully used up - occupied by the judiciary. The prisoner suffers precisely because he is not free, because he has been deprived of freedom, because he has no free time (even if he has a lot of time for himself) while serving his punishment. Thus, for example, participation in various activities connected with movement recreation is in that case one of the forms of his resocialization provided for by the judiciary and the penitentiary system.

From that viewpoint, the slave's time is also non-free time; that is, fully appropriated time - occupied by the master, i.e., the owner of the slave.

A similar situation occurs in the case of the prisoner or slave's sleep. When one or them sleeps, their time is not free time, for at least two reasons.

First, that type of time - similar to the time of liberated individuals or other persons outside of prison is time occupied by physiologically determined processes that are necessary for the regeneration of vital human powers. It is time occupied by rest, which is necessary for biological renewal and existence. In that sense, sleep has somehow unintentional character, since it is an enforced, biologically determined, and periodical phenomena resulting from the organism's vital functions.

Secondly, a nap, sleep, or rest takes place during the serving of a sentence or at a time fully appropriated by the owner of the slave. Thus, it occurs in non-free time. That time is used by other subjects 
who have control of human beings deprived of their freedom. For that reason, the aforementioned - that is, enslaved - beings are not, in the Kantian sense, beings in themselves, but reified beings constituting - from the viewpoint of the society approving of slavery or prison as the precondition for resocialization - means for the achievement of a social order as a value that is the highest in a given situation; that is, which constitutes an aim in itself. In that sense, that aim is an absolute value and the prisoner or the slaves are relative values.

If given individuals are not deprived of knowledge that they are in a situation which is highly uncomfortable for them, they fill their consciousness with, inter alia, reflections concerning precisely that entanglement.

This refers also to unemployed persons and pensioners or those in retirement. Their time is always occupied time, even when they do not do a job or any other work.

Taking into account only the biological aspect of human existence - both in the case of the free man and the enslaved one - it can be proclaimed that their time is always occupied, even when they are deprived of awareness of their own existence. Their organisms are always occupied with maintaining vital functions; they are always active as functional structures according to Ludwig von Bertalanffy's understanding (von Bertalanffy 1984).

Considering that issue according to the cultural interpretation, in relation to traditionally understood free time, it may be stated that time dedicated to and filled with movement activity or recreation of any other kind is not, as a matter of fact, free time, since it is occupied by the activity that takes place. It is also occupied with various activities or considerations both before and after that activity.

\section{Time in the mirror of conventions}

For man conscious of his own being and the passage of time, free time does not exist in the present, the past, or the future (even if only for the reason that this time has not yet come into being).

If its existence is ever pointed out, this happens solely on the principle of the applied convention that authorizes the formulation of such a context of justification, which is coherent with it.

Both in the first and the second case we are dealing with conventionalism; that is, with the application of a convention confirming, on the one hand, that free time does not exist and, on the other hand, that it certainly is.

When it is assumed that free time exists, as is the case of research done on sport for all, it transpires that the formulation of a universally binding definition of free time is, as a matter of fact, an impossible task, just like many other notions characteristic of the humanities. For example, according to Karl Popper and others, any attempt to define religion, culture, personality or health includes a mark of fallibilism, which is noticed sooner or later - a harbinger of the future downfall; that is, a mistake, a shortcoming, a controversial statement (Popper 1977). Thus, those attempts leave some epistemological deficiency, as well as the impression that those interpretations can be changed, modified, or improved.

Whenever I analyze a definition of free time, I find that it is neither full nor universal; that it can only be referred to the context of the book or the paper in which it appears; that it is not up to the task and undergoes falsification when other theoretical assumptions, other viewpoints are assumed as the basis for consideration. Thus, in the case of free time - as well as of other notions such as personality, health, culture, religion, education, etc. - we are dealing with plurality of standpoints, interpretations, considerations and definitions that are applied according to the chosen research option.

When the starting point is constituted, for example, by Mircea Eliade's philosophical and culturological conceptions, it turns out that man from the beginning of his history has organized his free time motivated by an idiogenetic - that is, innate - need to experience sanctity, and that the proper understanding of the world, of man's various aims or the issue of free time, is possible only in the sacral perspective (Eliade 1966, 1988). 
Naturally, such a perspective in considerations of free time, as with other more or less controversial conceptions, may arouse various reservations. Nevertheless, the impossibility of unambiguous specification of this notion does not mean that problems of free time should not be dealt with. Henri Bergson even maintains - giving the soul and the body as examples - that it is permissible to voice one's own views on various issues, to study and to define them and to write academic dissertations being unaware of their nature and without knowledge about what their essence consists of (Bergson 1963). It refers also to free time, even if you are of the opinion that this does not exist.

\section{Time From an Ontological and Epistemological Perspective}

Considerations about free time do not exempt us from the obligation not only to define how free time is understood, but also to explain the notion of time as such. This also applies to the dispute about its existence: that independent of position, viewpoint and convention, free, occupied and non-occupied time constitute parts of time as such.

In the presented text I will come down in favor of, first of all, the Kantian and Heideggerian interpretation of time. The combination of Kant and Heidegger's reflections consists of pairing up the concepts that according to the latter were mutually exclusive - that is, forming an association between what is subjective, and what is universal in comprehending time.

Time - as can be proclaimed on the basis of German hermeneutist views - is given to the subject by Being in an epistemic sense. The subject - as an organic entity - emerges only from Being, and time can be perceived by man only in an intuitive way - in a clearing - and only in extremely unique situations. In spite of that, it has - as will be shown later - universal character.

On the other hand, according to Kant's interpretation, time has an a priori character because it does not have a posteriori qualities. It is also subjective, since it is perceptible as a clear non-materialized envisagement springing from abstraction. It is also constantly perceived - similar to, in Heidegger's case (although with a different context of justification) - an intuitive way.

\section{Kant and time}

If we perceive time in a Kantian way we may proclaim that it has an anthropological character. It is a strictly human property. It is, regarding its source, anthropocentric, since it derives from man and can be thought and perceived only by him. It is a man-made conception, but it is not "a discursive or, as it is said, general notion" (Kant 1986, p. 109). It is subjective and simultaneously - as a "pure form of sensual envisagement" (Kant 1986, p. 109) - it has a priori character. It is not given from outside; thus, it is not an effect of extraspective experience, in spite of the fact that - from the common-sense viewpoint - its influence and passing, its effects are constantly experienced (Kant 1986, p. 107). "Time is not", as Immanuel Kant writes, "something existing for itself or something things are entitled to have as their objective description" and "it is not anything else, but a form of an inner sense (...) it cannot be a description of external phenomena" (Kant 1986, pp. 110-111). It is not given to us a posteriori "and that is why it must be possible to consider it completely separately from any sensation" (Kant 1986, p. 95).

According to Kant,

"Time is a necessary idea which underlies any envisaged data. It is impossible to completely remove time from phenomena, although it is quite possible to remove time phenomena. Thus, time is given a priori. The reality of phenomena is possible only in it. They can be eliminated completely, but time itself (as a general precondition of their possibility) is irremovable" (Kant 1986, pp. 107-108).

Time has neither universal nor objective qualities, since every individual experiences it and describes in a different way. If it is not universal and objective, it is relative - that is, relativized to a given individual. 
It is given to him in a direct way. He creates time and statements about its qualities. According to the Königsberg genius,

"time is only a subjective precondition, which is necessary for envisaged perceptions to take place in us, since only then that form of inner envisagement may be presented before things that is a priori" (Kant 1986, p. 111).

That is why it can be supposed that those "envisaged perceptions," "inner envisagement," and "a clear form of sensual envisagement" are, as a matter of fact, non-empirical intuitive cognition reaching directly what is abstract and what cannot be cognized in another way. Certainly "it is not intellectual perception" (Kant 1986, p. 136).

I agree with Kant that time is subjective ("outside the subject it is nothing", Kant 1986, p. 115) and that it has a priori character; it can be imagined and thought. His context of justification seems to be convincing in this respect. On the other hand, doubts may arise through the statement that it is given to the subject directly. Although the Königsberg philosopher clearly proclaims that it is given directly as abstract that is, clear - envisagement, he does not reinforce that statement with sufficient and necessary argumentation. In my opinion, Martin Heidegger's ontological views would be helpful in this case, and I will refer to them in a later part of my argument.

I am of the opinion that we experience time neither in the epistemic nor the ontic way. It can be only thought and, hence, intelligible in a causative sense which is not known to me. That is why it can be thought (it can be penetrated by thoughts in some sense, which cannot be defined by me) and it can constitute a foundation for epistemological reflection - though in spite of the lack of an epistemic basis. If time can constitute a basis for epistemological reflection, it can be ontologically characterized in spite of the lack of an ontic basis. Then we attribute to it properties of a hypostasis.

We experience only what happens during its lasting - i.e. we experience the effects of its lasting, which means all forms or manifestations of changeability accessible to us. If we experience its presence this takes place only in an indirect way - on the condition that it exists as a being: regardless of its form, even when it exists solely as a hypostasis. From that viewpoint, time is completely non-empirical. It has an $a$ priori character in that sense as Arch-four according to the Pythagorean interpretation, the Demiurge according to Plato's understanding, or the First Cause and the First Mover in Aristotle's philosophy. It can be cognized only intuitively, independent of experience. Perhaps it exists objectively, but it is impossible to irrefutably prove it - either in the epistemological or the ontological sense.

This is why it is difficult to define what time is and what its most important properties are.

The subject cognizes only manifestations of the influence of time, and time as such is in no way given to him as a set of definite properties.

Admittedly, defining time on the basis of the effects of its influence can be attempted, but this is not an argument that would be sufficient and justifiable for indisputably formulating statements about its ontological qualities, about its essence.

\section{Heidegger - Being and time}

Yes: I concur with Kant and Heidegger's view. Their conceptions of time connected into a specific selective whole seem to be the most proper from the viewpoint of considerations included in the text (that is, in a conventionalist sense). I act in such a way in spite of the fact that, according to Heidegger, time in Kant's interpretation has a "self-related" - that is, subjective - character, which is something, as I have pointed out, the German hermeneutist does not agree with (Heidegger 1986, p. 349).

Referring to his philosophy, time can be treated as a non-physical (that is, a non-material) and hence an abstract being and its manifestations (that is, objectivization of its possibilities, "enowning" or "properizing" (Heidegger 1986, p. 357) can be perceived in material entities - organic and non-organic ones 
- emerging from the abstract pre-ground called Being (Heidegger 1986, p. 353), constituting the foundation of the natural world.

Metaphysical Being is experienced by subjects in at least two ways. First, because it exists in a particular entity - e.g. in a human individual - in spite of the fact that the subject is unable to define its essence and other properties, whether it treats it as something which exists as a whole of incognizable and incomprehensible properties of metaphysical Being or as something which exists in particular entities (Heidegger 1994, pp. 493-510 and 567-610). Second, as a form of Being that can be directly experienced only in a clearing (Heidegger 1985, 1994, pp. 491-493). It appears extremely rarely, only in unique and outstanding subjects. They then become shepherds protecting the truth of Being (Heidegger 1985).

They start to be shepherds of Being, but also of its various forms of manifesting itself, including manifestations of time - that is, time not only as a pure abstraction unconnected with anything, but also as a metaphysical constituent dissolved in Being. First of all, however, they become shepherds of Being - that is, shepherds protecting the truth of being of time; shepherds who take care of its direct connections and oneway influence (since "the entity's being is care"), and who take care of immanent relations concerning the inevitable passing of time, which changes the human individual and the ecological niche, but not time.

Thus, the subject-shepherd protects existence - in other words, what exists in time. He protects the truth of being of his own existence. It gives the subject two aims to achieve - tasks with epistemological and anthropological overtones. First, he must protect the truth of what he has intuitively perceived in a clearing that appeared in him and what is the metaphysical and non-individual form of time dissolved in neverrecognizable Being, which can be perceived only with the help of artistic (and especially poetic), incommunicable intuition experienced in a deep - individual and subjective - way. Secondly, as a shepherd he must protect and take care of his own life (his own entity) - that is, that Being which saturates his entity with what causes its lasting and transformations.

Perhaps that abstract Being is simultaneously non-actualized time, that is - referring to Heidegger the Time from which everything results. Thus, it is the non-identified Being all entities - organic and nonorganic subjects and objects - emerge from, and they are inseparably connected with it, subjected to its influences, imprinted with its mark. On that basis it can be stated that Being is Time and Time is Being, shrouded with longer or shorter existing entities. Time and entities actualize themselves in a sense in the same way as - according to Maximus the Confessor - happened with the sexual intercourse of the first parents after they left proto-historical Paradise.

Heidegger, however, presents a different viewpoint when he proclaims that

Worldly time is, however, also more "subjective" than every possible subject, since that timein a properly understood sense of care as being of a really existing Self-makes only that being possible (Heidegger 1994, p. 585).

"Time" is present neither in the "subject" nor the object, neither "inside" nor "outside," and it "is" "earlier" than every subjectivity and every objectivity, since it constitutes a precondition of the possibility even of that "earlier." Thus, has it any "being" at all? And if not, is it an illusion, or perhaps something "being more" than any possible being? (Heidegger 1994, p. 585). Thus, the German thinker points out the possibility of the subjective experience of time, as the reason for and a manifestation of the subject's care and concern for what happens in himself and properizes itself in other entities. He also points out that it is not, however, something strictly subjective in the genesis-related sense - as it was in the case of Kant (although it can be subjectively experienced), since it originates neither from the subject nor from the object, it does not belong to them and does not depend on them. It exists neither inside the subject, nor outside of it. Heidegger points out that time is something which is both before and outside the subject as well as before and outside nature, that it is something earlier in its relations to entities (Nota bene: Heidegger also presents other descriptions of time: "Time is groundlessness of concentration which moves away" (Heidegger 1986, p. 357); "Time inhabits never moving" (Heidegger 1986, p. 358). The exegesis of their meaning would not, 
however, contribute much to understanding the text, since he considers a given interpretation of time in its relation to space.

What is common to Heidegger and Kant in their reflections on time is the subject's possibility of taking a subjective stance on it, even if there are doubts concerning the very existence of time. Although G. I. Berkeley maintained that to be is to be perceived, he proclaimed it as a proponent of extreme empiricism. His famous sentence might be recognized as legitimate in the field of the epistemology of time if that perception could also include intuitive perceiving.

On the other hand, what makes Heidegger different from the Enlightenment thinker - and what simultaneously can support and supplement his thoughts - is the view that in a clearing man may see the truth of Being and non-objectified time, which is grounded in it and which properizes itself in nature, although it is not its property. In that sense, what according to Kant was subjective takes on, thanks to Heidegger, a metaphysical non-subjective source character, as well as a pre-existential and universal basis. Thus, time - combining Kant with Heidegger and using notions of the Königsberg philosopher - is mediated in the noumenal world: the abstract or the metaphysical one, which is sensually inaccessible and perceived intuitively by the subject or in the subject when a direct possibility of experiencing what appears in a noumenal clearing becomes active in the discussed subject. That is why what is subjective in Kant's case loses its strictly subjective overtone and is compatible with the Heideggerian non-subjective, noncosmological, non-external (non-worldly and non-intra-subjective) conception of time, although only the subject can think about time and express about it more or less accurate opinions - including opinions on existence and possible properties of free, occupied, or non-occupied time.

\section{Heidegger and Greek philosophers' attitudes towards metaphysical matter}

Considering time according to its Heideggerian interpretation - as a being that is transcendental in its relation to nature and which also exists independent of man, who can intuitively and exceptionally perceive it in a clearing - it is possible to see that roots of Heideggerian ontology (including also his ontology and epistemology of time) reach not only the philosophy of the pre-Socratic Eleates - that is, in a given case, Parmenides' inquiries - but considerably deeper; that is, as far as the philosophy and metaphysics of nature of Anaximander - in my view the most outstanding philosopher of early Greek antiquity. The German hermeneutist was also - as I suppose - inspired by Plato and Aristotle and their metaphysics, and especially by conceptions of abstractly understood matter - that is, so-called prime or primary matter, possessing neither quantitative nor qualitative properties: non-physical, non-sensual and hence possessing a metaphysical status.

That is why the notion of the transcendental being (including also the Heideggerian Being and time, which is transcendental in its relation to entities) is applicable not only to one position in the field of the dispute on universals in its classical - medieval - as well as mathematical (presented by Willard Van Orman Quine in considerations entitled Z punktu widzenia logiki /From a logical point of view/ (Quine 1969, pp. 934) form, and not only to the notion of the Being, which is external in its relation to another, but also in relation to the preternatural, supernatural, supernatural, ideal, spiritual, absolute divine being.

That being - which is transcendental and simultaneously ideal - is perceived in the philosophical tradition in at least two ways: first, as a preternatural being of divine qualities (that is, sacred in some sense), but deprived of any connections with religion (that is, of abstract, metaphysical qualities); and, second, as the absolute sacred being marked with divinity and described by religious assumptions (dogmas) - that is, of religious, denominational provenance. 
In order to distinguish the ideal being which is purely philosophical and non-denominational from the notion of the divine being coming from a denomination, a distinction between those forms of being has been introduced. The first is called the transcendental being and the second - the transcendent being ${ }^{1}$.

\begin{abstract}
${ }^{1}$ It should be observed that in philosophy - as in the other humanities and not only in the humanities - there are no definitely shaped definitions of terms and notions and there will never be. This also concerns the notion of philosophy itself, which has as many interpretations as the number of proposals that have been presented by regarded specialists in the field.
\end{abstract}

The notion of the transcendental being has become so widely used that it has also permeated Kant's philosophy - and not only to his idealism (I would prefer to say: to his ontological dualism, as idealism may have also a monistic form), but also to the method, which was described as the transcendental method, and especially to the critique of the mind including aesthetics, analytics, and transcendental dialectics.

The conception of transcendentalism not only underlies his Critique of Pure Reason, but also his Critique of Practical Reason and his Critique of Judgment.

The noumenal world - that is, the world of things in and of themselves (of phenomenal beings), the world of pure intelligences - exists beyond the world of nature, beyond the world of phenomenal beings. It is external, i.e., transcendental, in its relation to material beings. It is indubitable. The situation, however, changes considerably in the last period of Kant's professional activity - that is, in his mystical period. What had been transcendental and was not associated with religion assumed a religious form. The notion of God as a purely philosophical being changes its meaning. It assumes a form of a religious or quasi-religious God - that is, a form of a transcendent being.

In the case of Kant's philosophy (but not only there) that distinction - that is, the distinction between the transcendental and the transcendent - appears to be useful.

It should be noted that in the world of philosophy - and generally in the humanities - the meanings of terms are changed and the latter are given new or modified meanings. In order to change the meaning of a term or notion, it is enough to formulate a proper - in the content-related and formal sense - context of justification for a different interpretation of the same term or notion. For example, ontological idealism is presented by Plato or Hegel in different ways; in each case this is done genially.

The fact that the notion of transcendentalism or the transcendental being are not reserved for considerations on universals and for Kant's philosophy is testified also by an already classic statement made by Leszek Kołakowski in the 1960s and included in his book Kultura i fetysze /Culture and fetishes/ in the chapter entitled "Range-Related and Functional Way of Understanding Philosophy." Thus, he presents there, among other things, the transcendental way of understanding philosophy referring first of all to E. Husserl (to his phenomenology) and to the philosophy of Descartes, who - while initiating modern rationalism - obviously did not suspect that such an important philosophical current as phenomenology was going to come into being.

Kołakowski describes Descartes' philosophy and Husserl's phenomenology (in spite of many obvious differences between them) as philosophies that are transcendental in their relation to - simplifying - the existing academic and philosophical tradition. The existence of the latter is suspended and philosophy and academic knowledge are built from the starting point in a way that is external - that is, transcendental - to the academic and philosophical status quo. Hence, a new philosophy as a being is external - that is, transcendental.

Thus, that interpretation goes beyond phenomenology. It refers also to Descartes and to philosophy in general as one of its definitions, i.e., definitions of the being of philosophy, of its genesis, and ontology.

The transcendental interpretation can be deepened - something which is not done by Kołakowski - by views of Hegel, who was of the opinion that both individual and social consciousness, self-knowledge, is given from outside by the Absolute. It refers to the ideas of the state, religion, art, and philosophy as the highest forms of self-realization and selfaffirmation. Thus, philosophy has (according to Hegel) a transcendental character in the source-related and evolutionary sense; it is a transcendental being in its relation to the human subject.

Using a distinction between "the transcendental" and "the transcendent" - which is applied not only by me - it is possible to notice that, for example, philosophy according to Aurelius Augustine's interpretation may - because of its genesis - be treated as knowledge given from outside by the Christian God with the use of illumination. When the aforementioned distinction is applied, we will be dealing with philosophy deriving from outside, given by God - that is, with a transcendent interpretation.

I do not agree - for two reasons - with the opinion that "the transcendental" has metaphysical character only when it is referred to universals. First, I issue the reminder that "the transcendental" is connected with only one option of a dispute on universals - namely, with realism - and not with conceptualism and nominalism (taking into account only three main positions of both the medieval dispute on universals and the contemporary discussion on universals in mathematics). Second, only Kant's idealism - and especially his ontological considerations - are connected with what is transcendental and transcendent according to the metaphysical interpretation, since the whole noumenal world is metaphysical in its relation to the phenomenal world (nature). The noumenal world is the world of things in themselves, of pure intelligences, and hence of metaphysical being. That is where, inter alia, Groundwork of the Metaphysics of Morals, and grounds for truthfulness of mathematical theorems (thus, according to Kant's opinion, of a priori 
The Kantian notion of the noumenal world and Heideggerian categories of Being and time constituting a pre-ground and pre-existential (metaphysical) foundation of that what is phenomenal in Kant's ontology and what is the entity in Heidegger's views - fall just into the range of the notion of the transcendental being.

\section{Anaximander's principium and Heidegger's Being and time}

Anaximander - the main Milesian philosopher - occupies among Greek naturalists a special place, since he was the first to abandon cognitive reflection based on the superficial observation of nature and he introduced speculative inquiries independent of empirical cognition - especially concerning the issues of the source (of transcendental character) and emergence of animate and inanimate matter (in fact, he was a hylozoist, since he emphasized that the whole of nature is animate, since it remains in constant motion). As a matter of fact, the basis and the source of ontological inspiration not only of philosophers of Greek antiquity, but also - especially important in the case of these considerations - of Heidegger himself is constituted simply by Anaximander's conception of metaphysical, abstract, continuous unchangeable, indestructible and immortal matter, which, according to Aristotle, was described by him as the first as the principium (Krokiewicz 1995, p. 79) - that is, the principle - transcendental and fundamental apeiron-boundlessness, a reservoir of matter, infinity, indefiniteness.

Admittedly the German thinker does not mention it, but - I believe - it is indubitable that the ontological conception of his "Being and Time" derives, more or less indirectly, just from Anaximander's "pan-reality" divided into two parts. One of them is constituted by the infinite multiplicity of particular worlds, and the other by the infinite and still principium, which has the character of the sovereign and ultimate reality and which - unlike the first part - is sensually inaccessible and can only be perceived by thoughts (Krokiewicz 1995, p. 82).

It is just there where the germ of Heideggerian conception of metaphysical Being (of unique properties and values of, among other things, the source and the cause, which are stressed also with the capital "B") and entities originating from it can be found. That Being is, according to Anaximander's interpretation, nothing else but the principium, metaphysically conceived nature, which is abstract, boundless (as the first principle and element he assumed that which is boundless) (Diogenes Laertios 1982, p. 77) and indefinite essence, which is the source of inexhaustible and endless resources the whole "infinite multiplicity of particular worlds" (Krokiewicz 1995, p. 83) gradually and continuously emerges from. It, unlike the metaphysical nature, exists in time, arises and dies, changes more or less in the physical respect depending on its qualitative and quantitative properties. Thus, together with the physical world, time (eternally existing and remaining as if in lethargy) originates and its properties - which in the abstract world, similarly as properties of the physical being, are included in the realm of possibility - manifest themselves.

The unchangeable sequence of originating and dying worlds and their history are

"determined by mighty and just time, a symbol of the boundless principium (...). 'Time' is only where there are worlds. Where there are none - that is, in the principium - (...) there is only constantly unchangeable 'eternity'” (Krokiewicz 1995, p. 82).

This leads to the conclusion that although time is primarily and, according to common sense, associated with nature, it does not belong to it as its essential internal property. Admittedly, it underlies it as the principium or Heideggerian Being, but - as in the famous hermeneutist's works - it is neither intraworldly (or intuitively perceived by unique entities-subjects), nor worldly (that is, objectively given, as in the case of Isaac Newton or Albert Einstein's views). It emerges from the abstract principium and from metaphysical Being. It is still something sufficiently abstract and ideal to be "divine," something showing

propositions, which are always universal and necessary), originate. Their grounds have a character that is metaphysical and simultaneously - which is obvious - transcendental (and in the period of Kant's mystical orientation it has a transcendent character). 
changeability and temporalization of the cosmos, and - considering its source - it initiates and stops its activation and eternity in the foreground, that is, in the Being and in the principium.

\section{Pythagorean Arch-four and time}

A similar view - in the sense of a transcendental and metaphysical viewpoint in reflection on nature and its cause (with a different context of justification) is presented by Pythagoreans. They assume (by the way, in their case we can use the category of collective consciousness, common philosophical knowledge) as is maintained by Aristotle (Krokiewicz 1995, p. 97) - that the number "is the principium both in the meaning of matter for existing things [that is, primary matter, metaphysical matter - my parenthetic remark] as well as in the meaning of the form" (Krokiewicz 1995, p. 98). It refers to the number ten, which was worshipped by Pythagoreans as the arch-perfect number that includes the whole essence of numbers. They called it "Arch-four." They drew, however, a significant distinction between the ten and the Arch-four. "Creative power (dynamis)" was ascribed by them only to the latter, and they described it also as the source and mainstay of the eternal current of nature (Krokiewicz 1995, p. 97). It constitutes the essence of the sensual world, determines its dimension, shape and quantity of particular parts as well as the unity and the shape of the whole (Krokiewicz 1995, p. 99).

Both the abstract reality and the sensual reality emerge from the Arch-four. That Pythagorean absolute exteriorizes from itself (since it has also those properties) both matter of metaphysical qualities and numbers (nota bene Aristotle was aware that Pythagoras regarded the "number" as the material and formal reason of all "objects" (Krokiewicz 1995, p. 100). That number performs in a way the function of Aristotle's form - it gives the first matter, by coming into a close direct connection with it - quantitative and qualitative perceptible properties. Other numbers exist independently of things and of the human mind.

That is why we are dealing with an anti-psychological stance pointing out that besides the physical world there exists also a supernatural world composed of numbers, which can be - in the nomological sense (in contrast with the nomothetic interpretation) - gradually discovered, explained, and understood by man only through his mind. Those numbers, similarly to Aristotle's form, dynamize physical matter that has come into being; they stimulate it for changeability. They mark it with a stigma of time. Temporalization of nature is in a way its most important feature, since it cannot exist beyond time.

Time is a primarily metaphysical category originating from the Arch-four constituting the form of forms of the physical world. In that sense, time is not a property of nature; it is a property of the abstract form, which is not, after all, a part of the potential sensual world, but only its stimulator and energy. Thus, time is mediated in the metaphysical foundation of the cosmos and results only from it. Things appear and disappear. The metaphysical foundation of the world is eternal and completely independent from nature and entities.

The Arch-four is an almost mature conception of the philosophical absolute. Pythagoreans developed in that respect an idea of Anaximander, who treated the principium also as a divine principle, which has neither a beginning nor an end, but as an endless, subtle metaphysically sublimated body. He worshipped its divinity similarly to how Thales worshipped the divinity of water. In that case we are dealing with sacrum; that is, with the aforementioned divinity of a non-denominational, strictly philosophical character.

Anaximander's (similar to those of Parmenides) views are closer to Heidegger's ontology than the metaphysical assumptions found in the philosophies of nature espoused by Pythagoras, Plato, and Aristotle, since in the latter, there can be found idealistic messages and heralds of the Hegelian Absolute. The Pythagorean Arch-four, as with the Hegelian absolute, exteriorizes from itself the metaphysical foundation of the phenomenal world. The Platonic Demiurge and Aristotle's First Cause found eternal, metaphysical matter without any quantitative or qualitative properties and they behave like divine constructors - they create the cosmos. Metaphysical time emerges from abstract matter and its properties - as in the cases analyzed in the text - can only be imagined. Heidegger rightly remarks that "Hegel with his interpretation of time moves unambiguously towards the common-sense idea of time" (Heidegger 1994, p. 601) proclaiming 
that "Time as the negative unity of being outside oneself is also something absolutely abstract and ideal. It is a being of such a kind that when it is, it is not and when it is not, it is. It is watched becoming, which means that differences, although absolutely momentary - that is directly undergoing annulment - become determined as external; that is, external in any case, if only in their relation towards themselves" (Hegel 1990, p. 258).

Hegelian characteristics of time - as is written, among other things, by the German hermeneutist in his long argument - assumes on the basis of "now" that the latter remains, considering its full structure, covered and smoothed away, in order to make it visible only as something "ideally" present (Heidegger 1994, p. 601).

In contrast to Hegel, all the discussed ancient conceptions of being and time have nothing to do with their common-sense interpretation, even those which to a smaller or a greater degree introduce the conception of the Absolute, the idea which was genially developed and presented by the German idealist at the beginning of the $19^{\text {th }}$ century.

\section{Parmenides - that is, Being as definitional Unity and multiplicity in perception}

In Parmenides' views - the closest to Heidegger's ontology - we are dealing with references to his predecessors' ontologies, although he uncompromisingly opposed them. In his considerations on beings, he came to the conclusion that the foundations of the sensually perceptible world are constituted by the constant, unchangeable, still, continuous, indestructible, complete and present Being, which does not include any void. He thought that there exists only "that which is (aeon)" - that is, being as such - and "that which is, is unborn and indestructible, since it is complete, still, and eternal (ateleston). It has never been and it will never be, since now it is at once complete, one and uniform" (Krokiewicz 1995, p. 145). There is only it and there is nothing else.

Aristotle, while interpreting views of representatives of the Eleates, appreciates Parmenides' perceptiveness as well as the fact that he not only perceives sensual beings but also recognizes them as worthy of philosophical reflection -

"although he postulates that there is no not-being besides being, he must admit that there is one

- namely, the Being and nothing else (...). Forced to abide by observed facts, he admits,

however, that the Being is Unity according to the definition, whereas it is multiplicity according to perceptions" (Arystoteles 1983, p. 20).

However, that being as multiplicity - in contrast to the prime (that is, essential and definitional) Being - is for Parmenides an apparent being, which is not understood by him, because it escapes rational perception. He is of the opinion that phenomena characterizing the phenomenal world - that is, multiplicity, movement, continuous change - can only be believed in by the subject, since it cannot know anything about them as they are sensual illusions (Krokiewicz 1995, p. 153). He understands, on the other hand, the world of intellectual notions he is in - that is, the real world, the metaphysical Being.

This leads to the conclusion that time and space have been placed in the metaphysical being - which can be cognized only by reason - independent of the sensual world. If it is assumed that what is sensually perceived emerges from the intelligible Being perceptible for thoughts, this means that nature - as in Heidegger's views - is entangled in time which is neither outer-worldly, nor intra-worldly; neither subjective, nor objective. It is - as in Kant's case - perceived subjectively, but it is also (like in Heidegger's work) metaphysically determined, dissolved in the Being, and perceived only by clearings. Thus, time is consequently an abstract category - both before and after objectification and dynamization of the world of nature.

In the metaphysical world, like in the cases of Heidegger and other aforementioned post-Anaxagorean ancient philosophers that dealt with nature, time has strictly potential properties. They exteriorize themselves, becoming active together with the emergence of nature. From the specified Being - that is, the 
metaphysical being - the material, sensually perceptible being comes into existence. Time influencing the whole of nature also emerges from that Being, but - unlike nature - it is not sensually perceptible at all, because it has no physical properties, in spite of the fact that it influences the spatial - quantitative and qualitative - world without exception and brings about inevitable changes in it. Among the fragments (entities) of the surrounding physical reality, only it still completely preserves its abstract qualities. Time is not sensually perceived by us; it is not defined in an ontological/empirical sense. It can be only thought and intuitively, directly cognized - in a Bergsonian way. Its existence is only supposed by us.

In the conceptions of nature of all the thinkers discussed here, time consequently preserves its metaphysical qualities. Before the objectification of nature, metaphysical had potential character, after making it physical the qualities of time become objectivized in spite of the fact that they still are not perceptible by human senses.

\section{Platonic time as an image of the eternal being}

Plato - as proclaimed by Diogenes Laertios (1982, p. 194) -

"postulated two beginnings of the universe: the god and matter. The god is called by him reason and cause, whereas matter from which complex things come into existence is regarded by him as shapeless and boundless. Then he says that when matter was moving chaotically, god gathered it in one place, regarding order to be better than chaos".

In Platonic ontology, God, called also the Demiurge, the Creator or Father, created from non-sensual matter the perfect - in the construction-related and functional sense - "body of the world", which is called, after Pythagoreans, the cosmos - that is, the order. "Considering the shape," writes Plato, "God gave the world such a shape which matched him the best and which is the most similar to him" (Platon 1986, p. 40). God gave it "a smoothed away uniform body (...) the full perfect body composed of perfect bodies" (Platon 1986, p. 41). The basis of the creative plan is general proto-patterns, that is, eternal ideas. The world created by the Demiurge also remains in constant motion. Because of hylozoist assumptions, time - as a being or a hypostasis that is also connected with organic movement - must appear.

"When Father gave birth to the world", writes Plato,

"he noticed that it moves and is alive - that world, which had become an image of eternal gods (...) he tried as much as was possible to make that world eternal (...). Hence [God] decided to create some image of eternal movements and, dealing with creation of the heaven, he created an eternal image of the eternal, still, one being, and he made it act according to mathematical laws - we call it Time" (Platon 1986, p. 45).

In that sense, Time as such "is not entitled to have any attributes which the process of becoming gives beings moving among sensually perceptible things" (Platon 1986, p. 45) and it moves - as is emphasized by Plato, who refers to Pythagoreans - "according to mathematical laws" (Platon 1986, p. 46).

Plato presents a conception of time different from the common-sense one - a transcendental conception of time, which has its basis beyond the physical world. Time reflects eternity and abstract mathematical laws. "Time existed, exists and will exist," because it was created "according to the model of eternal substance" (Platon 1986, p. 46) and that model is "the eternal being" (Platon 1986, p. 46). It originates from the metaphysical boundlessness, from the non-material world, but it is perceptible, since it activated itself, externalized itself - "it was born together with heaven." And because the physical world and the philosophical subject have come into being, it is possible to comment on it and formulate statements about it.

Time may also come into existence as objectification of one of the eternal ideas of abstract character and that idea is inseparably connected with every form of matter - both with first (metaphysical) matter as well as with sensual (physical) matter. In the first case, both time and its qualities exist potentially - time is dissolved in eternity - whereas in the second case the qualities of time become actualized. Movement and 
time, which is connected with it, accompany transformations of the universe; they make it worse as the whole. The whole world becomes more and more removed from perfection.

\section{Aristotle - that is, time as metaphysical perfection}

On the other hand, Aristotle's Absolute - the First Cause and simultaneously the First Mover - is treated by the Stagiryte not so much as the creator, but as the builder of the universe, who constructs the world from the first matter. It is also called - because of its metaphysical, abstract properties - the non-being from which the perceptible being emerges. Aristotle writes that "coming into being from the non-being takes place when [something emerges from] the imperceptible (...) coming into being does not stop, since coming into being is destruction of the non-being, while destruction is coming into being of the non-being" (Arystoteles 1981, p. 20). Thus, a given being comes into existence from the non-being - that is, from matter (from the abstract first matter) and as a result of activity of the intentional reason. Aristotle states, "Everything which comes into existence comes into existence either as a result of something (I mean as the beginning of becoming), or of something (I mean again not as lack, but as matter)" (Arystoteles 1983, p. 175). He confirms this, among other things, by writing elsewhere that "everything which comes into existence - either from nature, or by art - contains matter" - that is, the first matter (Arystoteles 1983. p. 172).

He continues that thought in another place, emphasizing that the first matter "is first in two senses: either first in its relation to the very subject, or first at all" (Arystoteles 1983, p. 110). All things have their "nature" composed of matter and form; it is their essence (Arystoteles 1983, p. 110). It should be noted that the notion of "nature" also appears in different meanings (Arystoteles 1983, pp. 108-110). Thus, for example, Aristotle calls "nature" also "the primary element some natural object either is constructed of, or comes into existence from - that is, the object which is non-shaped and unable to change by its own power" (Arystoteles 1983, p. 109) - such as, for example, bronze, which is processed by a sculptor into a statue. The first matter is preserved in such an object (Arystoteles 1983, p. 109).

As a result of activity of the intentional reason, spatial movement and circular movement appear. The first is "the first kind of change, and circular movement is the first kind of spatial movement, which is produced by the First Mover. Thus, the first mover is a necessary being" (Arystoteles 1983, p. 314), which because of its nature - is still and eternal (Arystoteles 1983, p. 317). Aristotle also gives the names of the divine Reason in his "Metaphysics": the First Eternal Mover and the God-Reason.

"The God-Reason" - states A. Krokiewicz in speaking about the Stagiryte's metaphysics -

"is the clear power and he thinks only himself with extensive substrata, so that they all constitute together the whole of the phenomenal universe, which remains in constant motion and which may be called the field of activity of the principal force - that is, of the transcendental God-Reason" (Arystoteles 1983, p. 329).

He continues by pointing out that Aristotle expresses an opinion that "actuality (activity) of the GodReason is life, and He himself is that actualization," as well as that "His thinking (noesis noesos) is so powerful that it causes life-existence of the phenomenal Universe" (Krokiewicz 1995, p. 329).

Movement and time as qualities of the first matter exist in it in the realm of possibility, since the whole matter has potential qualities. They are activated by the form that contains the reason, energy, and aim that define the sequence and duration of the transformations taking place one after another, as well as their definite end. The form of forms - that is, the First Cause and simultaneously the First Mover - brings about the coming into being of the world (that is, of nature) and the appearance of eternal movement in it. Time may in that case come into existence for two reasons. Either it is included and dissolved in the abstract, nonsensual first matter and becomes active together with movement, or its coming into existence and lasting are stimulated by the First Mover. 
Both in the first and the second case time as abstraction concerns what is quantitative and qualitative, sensually perceptible beings, the whole nature. Both it and human subjects - also continuously active remaining in constant motion and aware of its lasting - are inevitably and necessarily influenced by it.

But time - as Aristotle writes - in spite of the fact that it concerns the sensual world, is something metaphysically perfect. "That is called 'perfect' [complete] which has not even the smallest of its parts to be found outside of it; for example, the time of every thing is perfect [complete] when no other time being its proper part is to be found outside of it" (Arystoteles 1983, p. 134).

Thus, time - regardless the conception of its origin - is a being in itself. It is neither the attribute of the first matter - although it emerges from it and become active thanks to God - nor a property of the cosmos, although entities-subjects notice it and refer subjectively to it. It exists for itself, although it is not and cannot be constituted by itself.

\section{Summary}

In the above considerations I referred to a subjective and simultaneously universal and abstract concept of time based on combining assumptions of transcendental aesthetics, which characterize time and are included in Kant's critique of theoretical reason, with Heidegger's ontology. I also pointed out that Heidegger's views and his philosophy of time are rooted first of all in the philosophy of Greek antiquity. This refers especially to the metaphysical pre-being - indefinite abstract matter - and to activation of its sensual ("aesthetical," according to Kant's terminology) properties. Together with their appearance - either as a result of creativity of the Arch-four, the Demiurge or the First Cause, or as a result of spontaneous causative power of the divine principium, or of autotelic activity of Heidegger's Being - properties of time become active. They exist always - as a perfect image of the eternal being, as an abstraction impossible to be defined - both when it saturates or exists independently or at the basis of the metaphysical world of all things as well as when it influences nature, the cosmos.

In the German thinker's philosophy of Being and time, the aforementioned views of the ancient philosophers are consolidated as the source-related and content-related context of justification, which against its intentions - strengthens and lends credence to Kant's conception of self-related time. It takes place mainly thanks to the philosophical method applied in his considerations. Namely, both thinkers - Kant and Heidegger - used the intuitive method while simultaneously rejecting the common-sense - met, for example, in Hegel's case - understanding of time. Kant considered time as clear subjective envisagement reaching that which had not been precisely defined by him and which is non-sensual and simultaneously super-individual and universal. Heidegger maintained, also on the basis of philosophical intuition, that what is super-individual is, as a matter of fact, universal, since it has transcendental, non-subjective character. However, that which is transcendental can be not only thought (as in Kant's case), but also intuitively and subjectively perceived in a clearing of Being, which appears only in subjects and solely in people of unique poetic talent. In short, the difference between the two philosophers is in principle that, according to Kant's opinion, every subject can intuitively perceive abstract time, whereas, according to Heidegger, every human being can think time and encompass results of its influence with care, since he is a shepherd protecting the truth of Being and protecting and taking care of himself. Thus, he refers to time he has thought. Moreover in extremely unique cases - he can perceive it in a clearing. That is why in Heidegger's case perception of time by the subject (at least before it comes to intuitive clearing) has - as in Kant's case - a self-related character. Another epistemological step on the way to its intuitive perception is transcendental intuition justifying universal and abstract properties of time.

The above ontological and epistemological considerations on time lead to the conclusion that both conceptions of working time and free time have definitions and justifications of a common-sense character, because it is pointed out in them that man has time and that he has it at his free disposal, whereas from the viewpoint of the aforementioned conceptions it is the man who is subjected to influences of time irrespective of his will. It happens so because according to the assumptions of the conception of occupied and non- 
occupied time presented in the first part of the text, the subject never has time at its disposal, because time colloquially called "its time" is always, as a matter of fact, occupied and the subject will never free itself from it - that is, from being subjected to time.

That is why time, when referring to entities, to the subject, can be treated neither as free nor as nonfree. But in spite of its full independence, which is transcendental in its relation to entities and the subject, it constantly influences them. The man as the whole is saturated with, is occupied by time, since - regardless of whether he works or rests, sleeps or is alert - he cannot free himself of its influences, of changes connected with its influence. The man cannot free himself of time. That is why he cannot have free time. Free time would be time free of its influence.

Time, according to Kant and Heidegger's interpretation, was introduced in order to attempt to grasp and explain a strictly subjective and necessary connection with it, in spite of the fact that it has simultaneously a metaphysical, super-individual and transcendental character, and in order to point out that it is an illusion to think that we can have it at our disposal in the colloquial sense. From the philosophical viewpoint we are always entangled in the connection with time; we, as organic beings, are always occupied by time. That is why there is no free time and why man cannot have free time, since - regardless of what he does: work, deal with something else, or even do nothing - he always has to contend with occupied time. Colloquially speaking: free time does not exist. It does not concern the subject's past, its future, or its present.

\section{REFERENCES}

Arystoteles (1956). Etyka nikomachejska /Nicomachean Ethics/. Warszawa: PWN.

Arystoteles (1988). Zachęta do filozofii /Invitation to Philosophy/. Warszawa: PWN.

Arystoteles (1983). Metafizyka /Metaphysics/. Warszawa: PWN.

Arystoteles (1981). O powstawaniu i ginięciu /On Coming-to-Be and Passing Away/. Warszawa: PWN.

Bergson, H. (1963). Dusza i ciało /Soul and Body/. In Myśl i ruch /Mind and Motion/ (pp. 135-165). Warszawa: PWN.

Von Bertalanffy, L. (1984). Ogólna teoria systemu /General Theory of System/. Warszawa: PWN.

Diogenes Laertios (1982). Żywoty i poglady stynnych filozofów /Life and Views of Famous Philosophers/. Warszawa: PWN.

Dumazedier, J. (1962). Vers une civilisation du loisir?/Toward a society of leisure/. Paris: Ed. du Seuil.

Eliade, M. (1988). Historia wierzeń i idei religijnych /History of Religious Beliefs and Ideas/. Warszawa: KiW.

Eliade, M. (1966). Traktat o historii religii /Treatise on the History of Religion/. Warszawa: KiW.

Hegel, G.W.F. (1990). Encyklopedia nauk filozoficznych /Encyclopedia of the Philosophical Sciences/. Warszawa: PWN.

Heidegger, M. (1985). Człowiek jako prześwit - pasterz chroniący prawdę Bycia /Man as Clearing - Shepherd Protecting the Truth of Being/. In J. Kosiewicz (Ed.), Wspótczesna filozofia człowieka /Contemporary Philosophy of Man/ (pp. 51-61). Warszawa: Wydawnictwo AWF.

Heidegger, M. (1994). Bycie i czas /Being and Time/. Warszawa: PWN.

Heidegger, M. (1993). Sein und Zeit. (17. ed.)/Being and Time/. Tubingen: Max Niemeyer Verlag.

Heidegger, M. (1986). Przyczynki do filozofii ( $z$ wydarzania) /Contributions to Philosophy (from Enowning)/. Kraków: Wydawnictwo Baran i Suszczyński.

Heidegger, M. (1989). Beitrage zur Philosophie (vom Ereignis) /Contributions to Philosophy (from Enowning)/. Frankfurt nach Main: Vittorio Klosterman.

Hodan, B. (Ed.) (2002). Volny cas a jeho soucasne problemy /Free time and ist contemporary assumptions/. Olomouc: University of Olomouc.

Kant, I. (1986). Krytyka czystego rozumu /Critique of Pure Reason/. vol. 1. Warszawa: PWN.

Kosiewicz, J. (2003). Bóg, cielesność i miłość /God, Corporeality and Lovel. Warszawa: Aletheia.

Kosiewicz, J. (2004a). Filozoficzne aspekty kultury fizycznej i sportu /Philosophical Aspects of Physical Culture and Sport/. Warszawa: Wydawnictwo „BK”. 
Kosiewicz, J. (2004b). Myśl wczesnochrześcijańska katolicka wobec ciała /Attitude of Early Catholic Thought to the Body/. Warszawa: Witmark.

Kosiewicz, J. (2006). Dispute on the Free Time. In Recreation for All (pp. 11-16). Legionowo: Economical and Technical College in Legionowo.

Krokiewicz, A. (1995). Zarys filozofii greckiej. Od Talesa do Platona, Arystoteles, Pirlon i Plotyn /An Outline of Greek Philosophy. From Thales to Plato, Aristotle, Pirlon and Plotinu. Warszawa: Aletheia.

Moltmann, J. (1995). Bóg w stworzeniu /God in Creation/. Kraków: ZNAK.

Platon (1986). Timajos. Kritias /Timaios, Kritias/. Warszawa: PWN.

Popper, K. (1977). Logika odkrycia naukowego /Logic of the Scientific Discovery/. Warszawa: PWN.

Popper, K. (1992). Wiedza obiektywna /Objective knowledge/. Warszawa: PWN.

Quine, W.V.O. (1969). Z punktu widzenia logiki /From a Logical Point of View/. Warszawa: PWN.

AUTHOR'S ADDRESS: $\quad$ Jerzy Kosiewicz Department of Philosophy, Chair of the Social Sciences Josef Pilsudski University of Physical Education in Warsaw 34 Marymoncka str., 00-968 Warsaw, Poland Email: jerzy.kosiewicz@awf.edu.pl 